University of Nebraska - Lincoln

DigitalCommons@University of Nebraska - Lincoln

Contact zone permeability at intrusion boundaries: new results from hydraulic testing and geophysical logging in the Newark Rift Basin, New York, USA

Jurg M. Matter

Lamont-Doherty Earth Observatory of Columbia University, jmatter@ldeo.columbia.edu

D. S. Goldberg

Lamont-Doherty Earth Observatory of Columbia University

Roger H. Morin

Denver Federal Center, roger.morin49@gmail.com

M. Stute

Lamont-Doherty Earth Observatory of Columbia University

Follow this and additional works at: https://digitalcommons.unl.edu/usgsstaffpub

Part of the Earth Sciences Commons

Matter, Jurg M.; Goldberg, D. S.; Morin, Roger H.; and Stute, M., "Contact zone permeability at intrusion boundaries: new results from hydraulic testing and geophysical logging in the Newark Rift Basin, New York, USA" (2006). USGS Staff -- Published Research. 354.

https://digitalcommons.unl.edu/usgsstaffpub/354

This Article is brought to you for free and open access by the US Geological Survey at DigitalCommons@University of Nebraska - Lincoln. It has been accepted for inclusion in USGS Staff -- Published Research by an authorized administrator of DigitalCommons@University of Nebraska - Lincoln. 


\title{
Contact zone permeability at intrusion boundaries: new results from hydraulic testing and geophysical logging in the Newark Rift Basin, New York, USA
}

\author{
Jürg M. Matter • D. S. Goldberg • R. H. Morin • \\ M. Stute
}

\begin{abstract}
Hydraulic tests and geophysical logging performed in the Palisades sill and the underlying sedimentary rocks in the NE part of the Newark Rift Basin, New York, USA, confirm that the particular transmissive zones are localized within the dolerite-sedimentary rock contact zone and within a narrow interval below this contact zone that is characterized by the occurrence of small layers of chilled dolerite. Transmissivity values determined from fluid injection, aquifer testing, and flowmeter measurements generally fall in the range of $8.1 \mathrm{E}-08$ to $9.95 \mathrm{E}-06 \mathrm{~m}^{2} / \mathrm{s}$ and correspond to various scales of investigation. The analysis of acoustic and optical BHTV images reveals two primary fracture sets within the dolerite and the sedimentary rocks - subhorizontal fractures, intersected by subvertical ones. Despite being highly fractured either with subhorizontal, subvertical or both fracture populations, the dolerite above and the sedimentary rocks below the contact zone and the zone with the layers of chilled dolerite are significantly less conductive. The distribution of the particular conductive intervals is not a function of the two dominant fracture populations or their density but rather of the intrusion path of the sill. The intrusion caused thermal fracturing and cracking of both formations, resulting in higher permeability along the contact zone.
\end{abstract}

Résumé Des tests hydrauliques et des sondages géophysiques réalisés dans la formation Palisades et les

Received: 24 January 2005 / Accepted: 8 March 2005

Published online: 3 November 2005

(C) Springer-Verlag 2005

J. M. Matter $(\bowtie) \cdot$ M. Stute

Lamont-Doherty Earth Observatory of Columbia University, Geochemistry, 61 Route 9W,

Palisades, NY 10964, USA

e-mail: jmatter@1deo.columbia.edu

Tel.: +1-845-365-8543

Fax: +1-845-365-8155

D. S. Goldberg

Lamont-Doherty Earth Observatory of Columbia University,

Borehole Research,

Palisades, NY 10964, USA

R. H. Morin

U.S. Geological Survey, Denver Federal Center,

Denver, CO 80225, USA roches sédimentaires sous-jacentes, dans la partie NE du rift du Newark, confirme que les zones transmissives sont localisées dans la zone de contact entre les roches sédimentaires et doléritiques, et dans un intervalle «en goulet》 composé de petites couches de dolérites, à proximité de cette zone de contact. Les valeurs de transmissivités, déterminées par injection, essais de pompages, et mesures des débits, sont comprises entre $8.1 \mathrm{E}-8$ et $9.95 \mathrm{E}-06 \mathrm{~m}^{2} / \mathrm{s}$ et correspondent à des échelles variables d'investigation. L'analyse d'images BHTV acoustiques et optiques, révèle deux lots de fractures dans la dolérite et la roche sédimentaire-fractures subhorizontales, intersectées par des fractures subverticales. Malgré des zones très fracturées, caractérisées par l'une ou l'autre voir les deux lots de fractures, la conductivité hydraulique est assez faible. La distribution des intervalles particulièrement conductifs n'est pas une fonction des deux lots de fractures dominants, ou de leur densité, mais plutôt du taux de pénétration des couches. L'intrusion provoque la fracturation thermique des deux formations, induisant une conductivité hydraulique meilleure le long de la zone de contact.

Resumen Pruebas hidráulicas y levantamientos geofísicos realizados en el manto interestratificado Palisades y las rocas sedimentarias subyacentes en la parte NE de la cuenca extensional Newark confirman que las zonas transmisivas particulares se localizan dentro de una zona de contacto dolerita-roca sedimentaria y dentro de un intervalo angosto por debajo de esta zona de contacto que se caracteriza por la ocurrencia de pequeñas capas de dolerita enfriada. Los valores de transmisividad determinados a partir de inyección de fluidos, pruebas de acuíferos, y estimaciones de mediciones de flujo generalmente caen en el rango de $8.1 \times 10^{-8}$ y $9.95 \times 10^{-6} \mathrm{~m}^{2} / \mathrm{s}$ y corresponden a varias escalas de investigación. El análisis de imágenes BHTV ópticas y acústicas revela dos conjuntos de fractura primarios dentro de la dolerita y las rocas sedimentarias: fracturas subhorizontales intersectadas por fracturas verticales. A pesar de encontrase altamente fracturadas ya sea con fracturas subverticals o subhorizontales o con ambas poblaciones de fracturas, la dolerita que se encuentra por encima, las rocas sedimentarias que se encuentran por debajo de la zona de contacto, y la zona con las capas de dolerita enfriada son significativamente menos conductivas. La distribución de los intervalos particulares 
conductivos no es función de las dos poblaciones de fracturas dominantes o de su densidad sino más bien de la ruta de intrusión del manto interestratificado. La intrusión causó fracturamiento termal y agrietamiento de ambas formaciones resultando en permeabilidad más alta a lo largo de la zona de contacto.

Keywords Fractured rocks - Igneous rocks · Groundwater hydraulics · Hydraulic testing · Geophysical methods

\section{Introduction}

This study focuses on the hydraulic and geophysical properties of faults and fractures in the Palisades sill and the underlying sedimentary rocks of the Newark Rift Basin, New York, USA. The geological and petrophysical characteristics of these formations have been investigated previously in numerous studies (e.g. Walker 1969; Olsen 1980; Schlische and Olsen 1990; Burgdorff and Goldberg 2001; Goldberg and Burgdorff 2005). The primary motivation for this study was the evaluation of the hydrogeologic properties of fractured intrusive and sedimentary rocks within their structural context.

Fractured rocks exhibit a wide variety of hydraulic responses that mainly depend on fracture distribution, orientation, frequency and interconnectivity. The characterization of fluid flow in fractured rocks is presented e.g. in Long et al. (1996), Singhal and Gupta (1999) and Faybishenko et al. (2000). Other published studies focus on nuclear waste repositories (e.g. Witherspoon et al. 1980; Ericsson and Almen 1992; Mazurek 2000) and groundwater contaminants in fractured rocks (e.g. Guimerà and Carrera 2000; Chen et al. 2001; Finsterle et al. 2002). The application of a multidisciplinary strategy, in particular the use of borehole geophysics and aquifer testing in fractured rock environments are essential to characterize such complex hydrogeological systems (e.g. Goldberg et al. 1994, 2003; Morin et al. 1988, 1997, 2000; Paillet 1998; Paillet and Reese 2000).

This paper presents new data from aquifer testing and geophysical logging in the fractured rocks of the Palisades dolerite sill and the underlying (meta-) sedimentary formations in the Newark Rift Basin. These detailed measurements provide evidence for enhanced transmissivity associated with the intrusion of the Palisades sill and the subsequent contact metamorphism.

\section{Hydrogeological setting}

The study site is at the northeastern end of the NE-SW elongated Newark Rift Basin on the Lamont-Doherty Earth Observatory campus in Palisades New York (Fig. 1). This basin is one of several continental rift basins along the eastern seaboard of North America and is a typical half-graben, bounded on its northwestern and northern margin by a system of normal faults and by the Hudson River valley on the NE and SW (Olsen 1980; Schlische 1992). The basin fill is

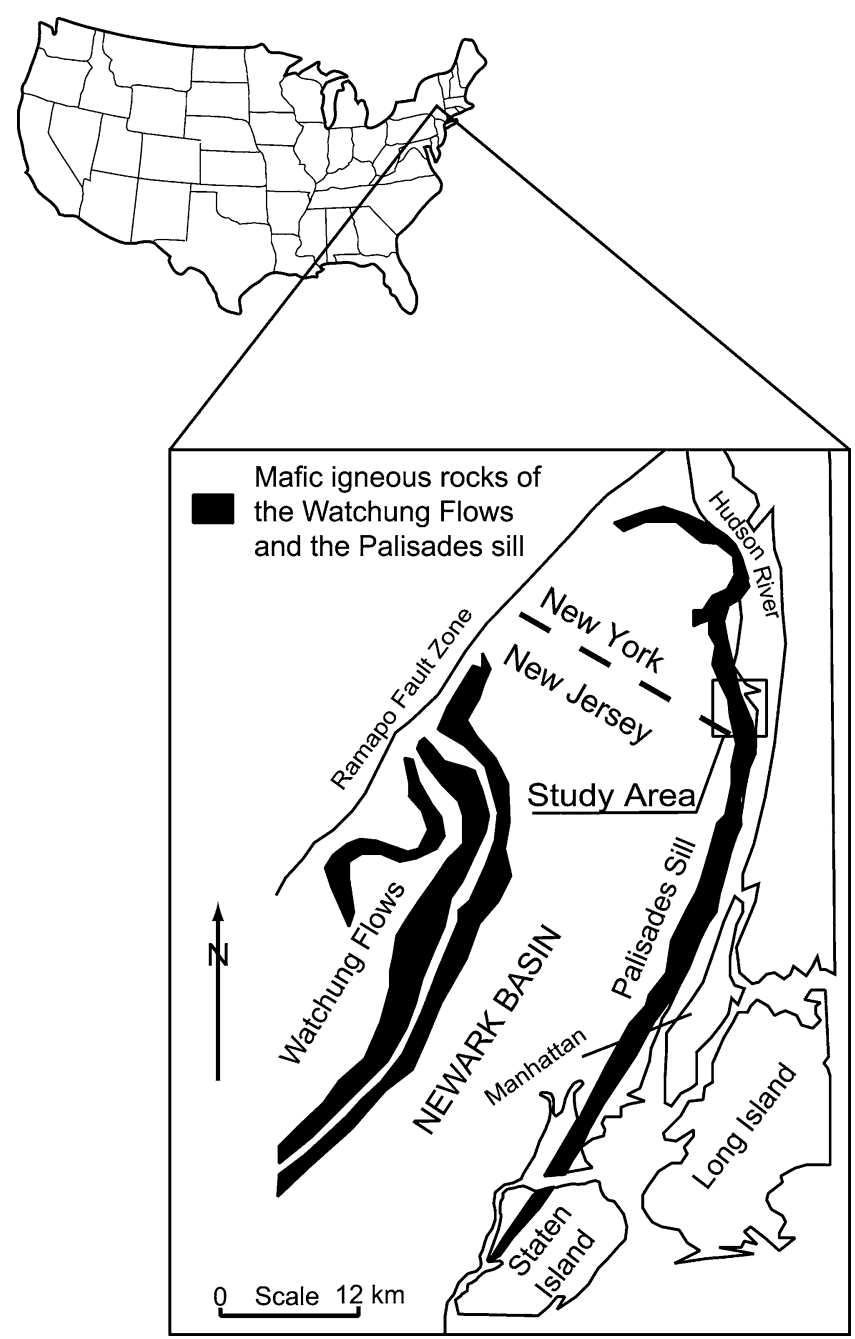

Fig. 1 Simplified geological map showing the mafic extrusive rocks of the Watchung flows and the intrusives of the Palisades sill, as well as the location of the study area

comprised of Late Triassic to Early Jurassic sedimentary and mafic igneous rocks; the sediments are exclusively of terrestrial origin and the igneous rocks include intrusives (Palisades sill) and extrusives (Watchung flows) (Olsen and Kent 1996). The study site is characterized by the outcropping Palisades sill, which forms the prominent escarpment along the bank of the Hudson River in New York and New Jersey for approximately $80 \mathrm{~km}$ (Fig. 1). The sill, which is $2.4 \mathrm{~km}$ wide and between 190 and $230 \mathrm{~m}$ thick at the study site, intruded into the Triassic sedimentary rocks of the Newark Rift Basin in the Early Jurassic. The contact between the Palisades sill and the underlying sedimentary rocks is discordant and truncates the bedding of the bounding sedimentary rocks. Regionally, the contact typically migrates up-section to the north. The sedimentary rocks along the contact have been contact metamorphosed and the contact zone is characterized by disrupted sedimentary bedding and contact-zone breccias. Van Houten (1969) notes that the original argillite of the Lockatong Formation has been converted into black hornfels by contact metamorphism. The sandy inter-layers have been altered 
LDEO-2
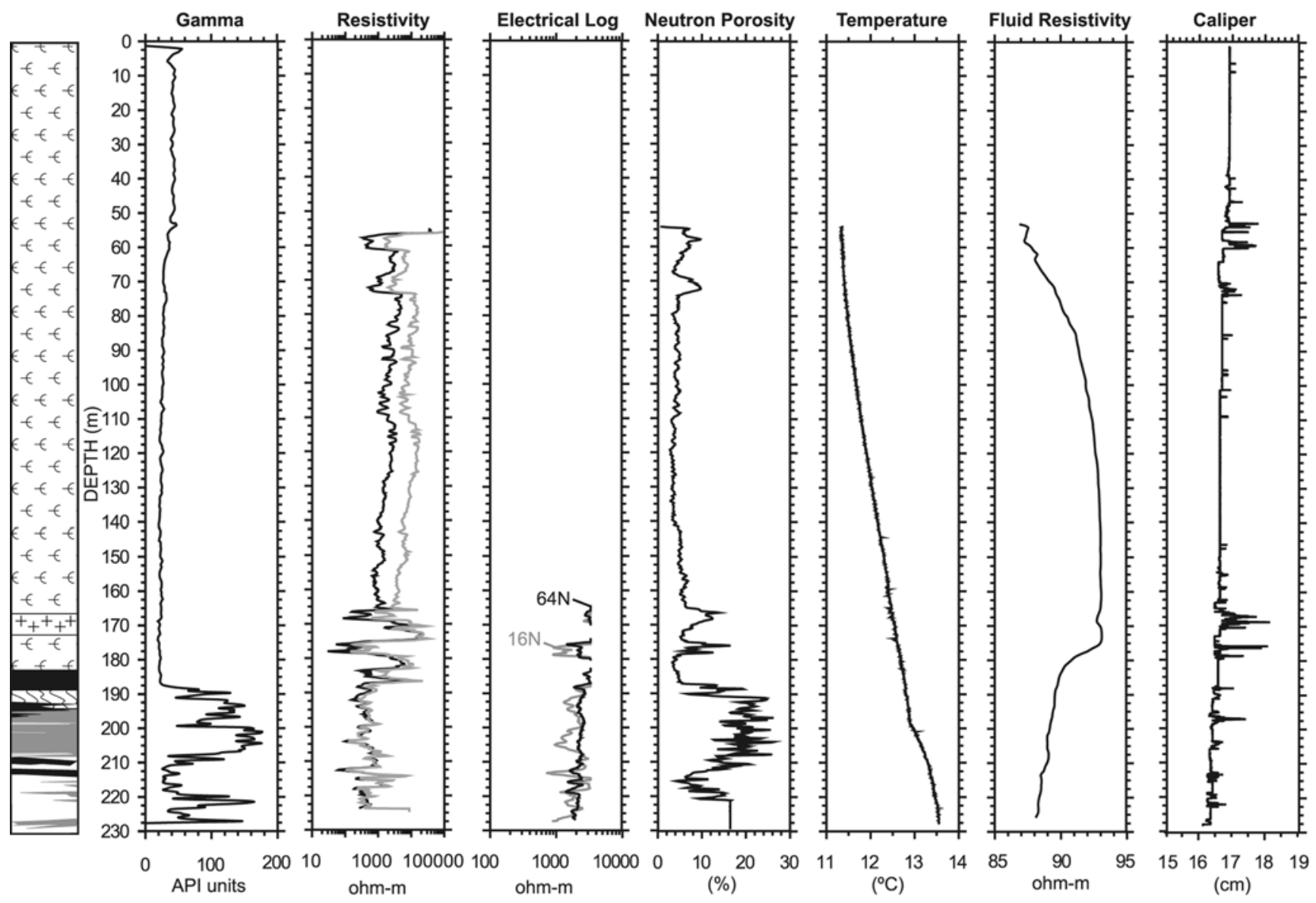

Lithology

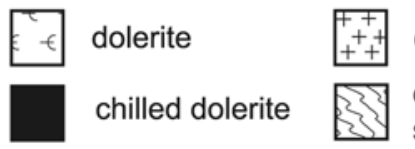

olivine-rich dolerite

contact-metamorphosed

sediments (metasediments)

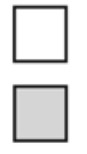

sandstone

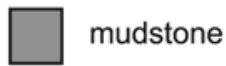

siltstone

Fig. 2 Composite logs of lithology in LDEO-2. Relative depth is indicated in meters, referenced to the top of the borehole (ground level). The log data (except Gamma and Caliper) are recorded from the nat-

to a lesser degree (Merguerian and Sanders 1995). These authors note further that the igneous-sedimentary interface is crosscut by "dikes" of sandstone that intruded into the chilled and fractured dolerite during cooling, which are comprised of an aphanitic to glassy texture that becomes gradually coarser with increasing distance from the contact zone.

The regional hydrogeology of the Newark Rift Basin has been described by Houghton (1990), Michalski (1990) and Michalski and Britton (1997). Fractured-rock aquifers define the principal groundwater flow systems on a regional scale, and in general, secondary porosity is more developed than primary porosity in the Newark Basin (Houghton 1990).

Two boreholes (LDEO-2 and LDEO-3) are of primary interest in this study, both approximately $900 \mathrm{~m}$ west of the escarpment, and separated by $450 \mathrm{~m}$. The boreholes are open holes and their total depth is $230 \mathrm{~m}$ for LDEO-2 ural water level depth $(\sim 55 \mathrm{~m})$ to $\sim 220 \mathrm{~m}$ depth in the borehole. The electrical log data are saturated in the dolerite where resistivity values are elevated. Modified from Burgdorff and Goldberg (2001)

and 304 for LDEO-3 (Burgdorff and Goldberg 2001). The topographical position between the two boreholes differs, with LDEO-2 located on the flank of a valley and LDEO-3 on a local high. Both boreholes penetrate most of the section of the Palisades sill and several tens of meters into the Newark Basin sediments (Burgdorff and Goldberg 2001). Based on drill chips, hand samples and thin sections, as well as geophysical logs, Burgdorff and Goldberg (2001) and Goldberg and Burgdorff (2005) characterize the petrophysical and lithological profile at this site (Figs. 2 and 3). Figures 2 and 3 also illustrate the complexity of the contact zone between the dolerite and the underlying sedimentary rocks. The difference in the sediment sequences between LDEO-2 and LDEO-3 is attributed to the irregular intrusion path of the sill, crosscutting the sediment stratigraphy (Burgdorff and Goldberg 2001). The contact zone with an approximate thickness of 10-20 m includes the chilled dolerite and the meta-sedimentary rocks (Fig. 4). In 


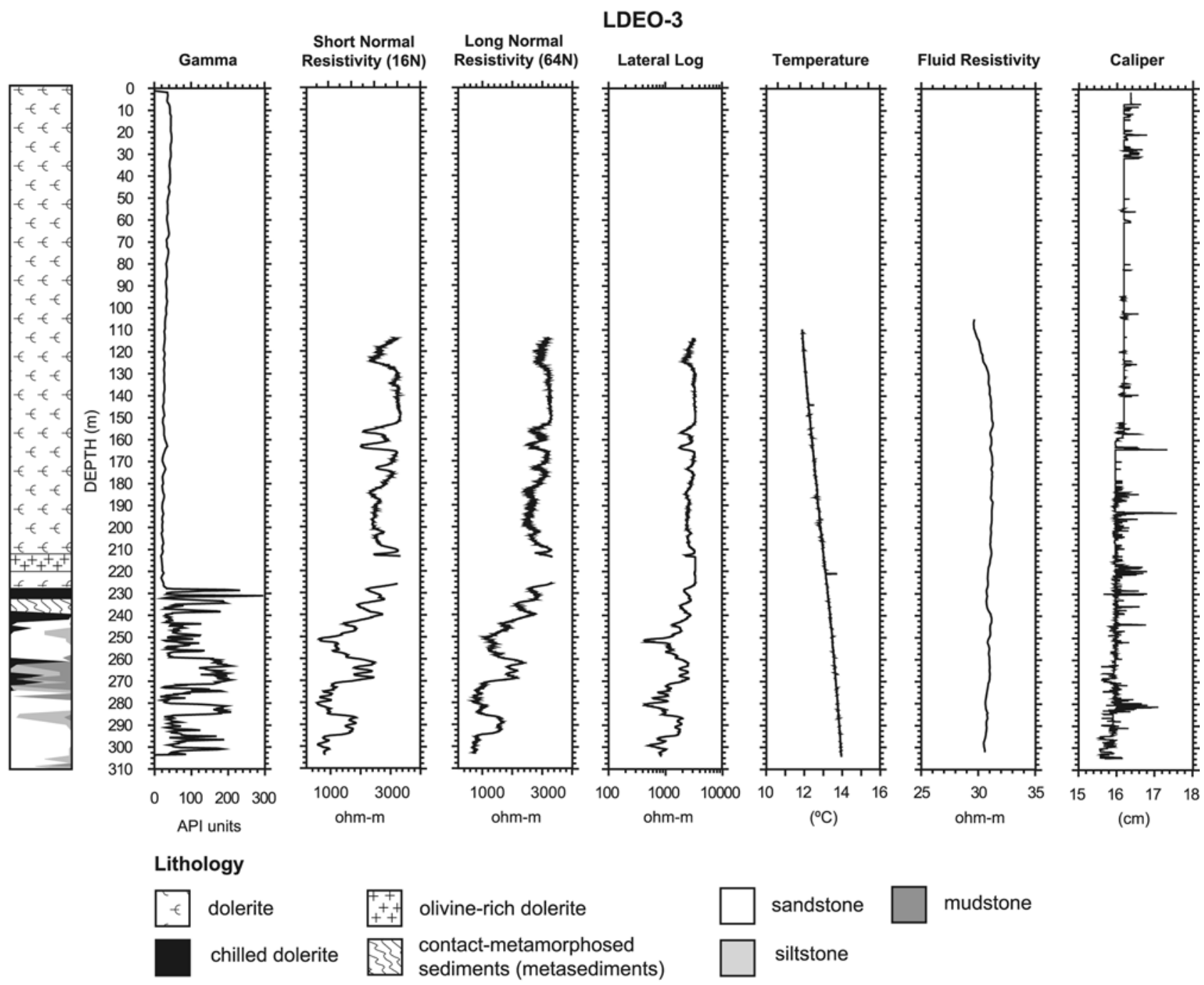

Fig. 3 Composite logs of lithology in LDEO-3. Relative depth is indicated in meters, referenced to the top of the borehole (ground level). The log data (except Gamma and Caliper) are recorded from

addition, several stringers of basalt occur up to $30 \mathrm{~m}$ below the contact zone, forming localized contact zones with the surrounding sedimentary rocks (Fig. 5).

\section{Methods and results}

\section{Hydraulic testing}

Fluid injection and constant discharge aquifer tests were conducted in LDEO-3 using a straddle-packer system to evaluate the transmissivity of specific intervals (e.g. Shapiro and Hsieh 1998). The straddle-packer arrangement allowed isolation of 3- and 10-m intervals. Caliper and televiewer $\operatorname{logs}$ have been examined to avoid damaged zones in the borehole for packer placement and setting. Water levels were measured continuously during and after each hydraulic test, using pressure transducers. Ambient water levels before testing were $54.5 \mathrm{~m}$ below ground level in LDEO-2 and $108.8 \mathrm{~m}$ in LDEO-3. No injection tests were performed in LDEO-2 due to limited access to the site. It the natural water level $(\sim 120 \mathrm{~m})$ depth and $\sim 305 \mathrm{~m}$ depth in the well. Modified from Burgdorff and Goldberg (2001)

was only used as an observation well during the hydraulic testing in LDEO-3.

Table 1 shows the depth interval and calculated transmissivity values in LDEO-3. With two exceptions at 214.5 and $264 \mathrm{~m}$, all fluid injection tests were conducted in isolated 3-m intervals chosen based on the borehole televiewer (BHTV) logs. Water was injected into each packed-off interval from the surface and the fluid pressures within, above, and below this interval were monitored using highresolution transducers. The injection flow rate was measured using a flow meter calibrated for $0.76-30.0 \mathrm{l} / \mathrm{min}$. The Thiem equation (Bear 1979) is used to estimate the transmissivity, $\mathrm{T}$, of each individual zone from flow rate and hydraulic head measurements. A radius of influence of $10 \mathrm{~m}$ is assumed for these calculations, which is based on measured values in fractured crystalline rocks (Shapiro and Hsieh 1998). All the tests were repeated while applying sequentially higher injection pressures. The calculated transmissivity values were not sensitive to applied injection pressures between 0.5 and $3.5 \mathrm{MPa}$ (Table 1). 


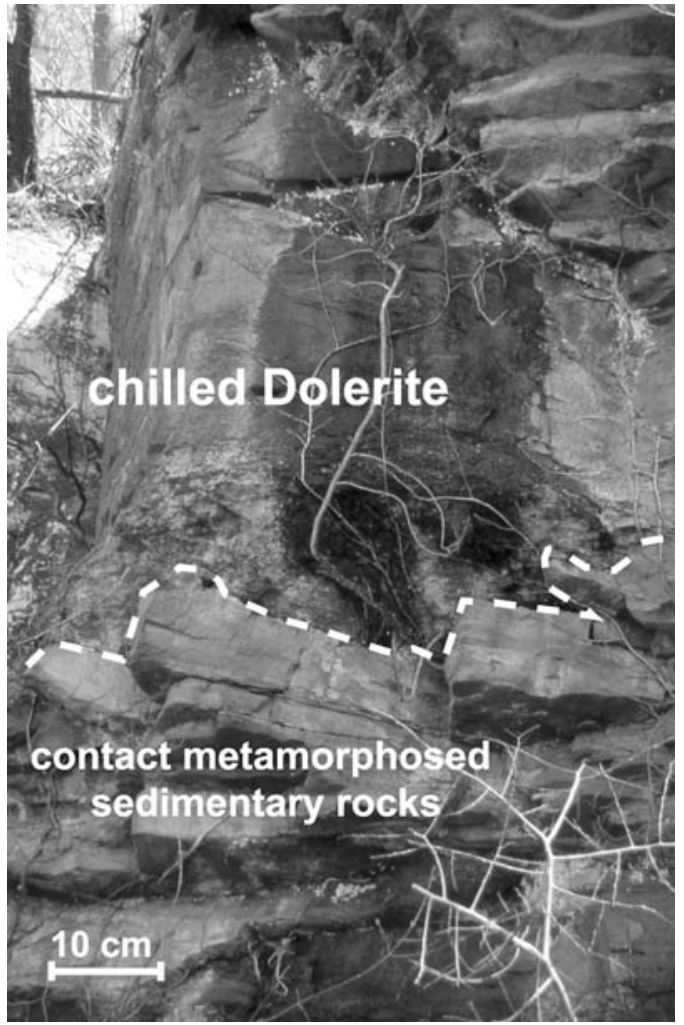

Fig. 4 Photograph of the outcropping contact zone between the dolerite of the Palisades sill and the contact metamorphosed Newark rift basin sedimentary rocks. Outcrop is situated a few kilometers to the north of the study area (photography from J. Goddard)

To widen the radius of investigation to tens of meters, a 30-hour single well constant discharge test was conducted in LDEO-3. This test probed the long-term hydraulic response of the contact zone and the underlying sedimentary rocks. A single packer system hydraulically isolated the contact zone and the sedimentary rocks from the overlying dolerite and the drawdown was measured. The bulk transmissivity was computed from this test using methods described by Cooper and Jacob (1946). This estimate is presented in Table 1.

As observed in Table 1, the active fluid injection tests reveal that there are only five zones that respond hydraulically during injection in LDEO-3. The results in all other zones are below the detection limit of the measurements $(<0.76 \mathrm{l} / \mathrm{min})$. Computed transmissivity within the packedoff intervals varies between $8.1 \mathrm{E}-08$ and $9.95 \mathrm{E}-06 \mathrm{~m}^{2} / \mathrm{s}$, with the highest value including the contact zone at 228$300 \mathrm{~m}$ depth. Note this $72-\mathrm{m}$ test interval is $10-14$ times larger than in the other injection tests.

In Fig. 6a,b, data from the constant discharge test and the derivative of drawdown are shown. Noise in the differential curve is reduced by applying a longer differential interval (Bourdet et al. 1989; Horne 1995). In this case, a value of 0.3 for the differential interval is used. The analysis of these data applying the Jacob straight-line method for confined and leaky aquifers (Cooper and Jacob 1946) reveals a bulk transmissivity of $6.28 \mathrm{E}-06 \mathrm{~m}^{2} / \mathrm{s}$ (Table 1 ).

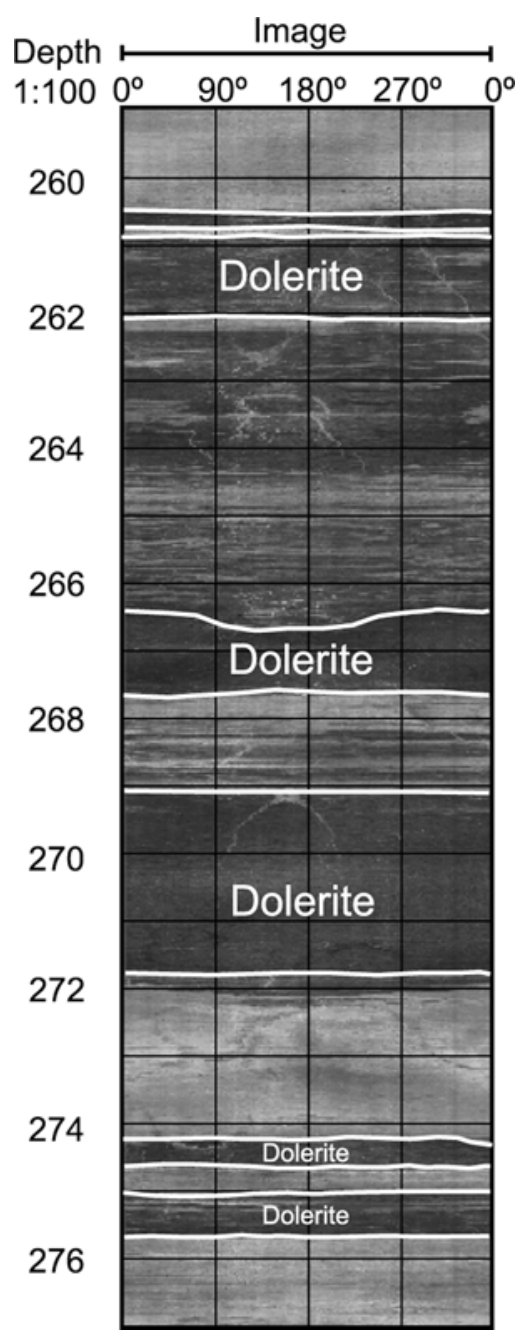

Fig. 5 Optical borehole televiewer image in LDEO-3, illustrating the zone that is characterized by the occurrence of several small stringers of chilled dolerite

\section{Geophysical and flowmeter logging}

Conventional geophysical logging including short-normal (16 in.) and long-normal (64 in.) resistivity, caliper, fluid resistivity, temperature, and digital and optical televiewer logs were collected in each well under static conditions prior to the hydraulic testing (Figs. 2 and 3). Burgdorff and Goldberg (2001) and Goldberg and Burgdorff (2005) describe in detail the geophysical logging methods and analyses used at these sites. The downhole temperature tool is a high-sensitivity probe with an accuracy of $\pm 0.05^{\circ} \mathrm{C}$. Flowmeter logs were conducted in each hole, using an electromagnetic flowmeter method (Molz et al. 1994; Young and Pearson 1995). Flowmeter data obtained under ambient conditions and during fluid injection allows the vertical distribution of transmissivity to be estimated (Morin et al. 1988; Molz et al. 1989). Once the hydraulic head has approached a constant value (pseudo-steady state), zones of fluid exchange between the borehole and the surrounding formation are identified. Flowmeter measurements that were made prior to injection revealed ambient flow below the flowmeter's response limit $(<0.05 \mathrm{l} / \mathrm{min})$, and therefore 
Fig. 6 Constant discharge aquifer test data from a single well test (squares) plotted in a log-log plot and b semi-log plot with regression line for the Jacob straight-line method. Derivatives of the drawdown (crosses) are plotted in a. The late-time constant head boundary effect is indicated by the declining derivative curve and by the constant drawdown (flat region) on these plots
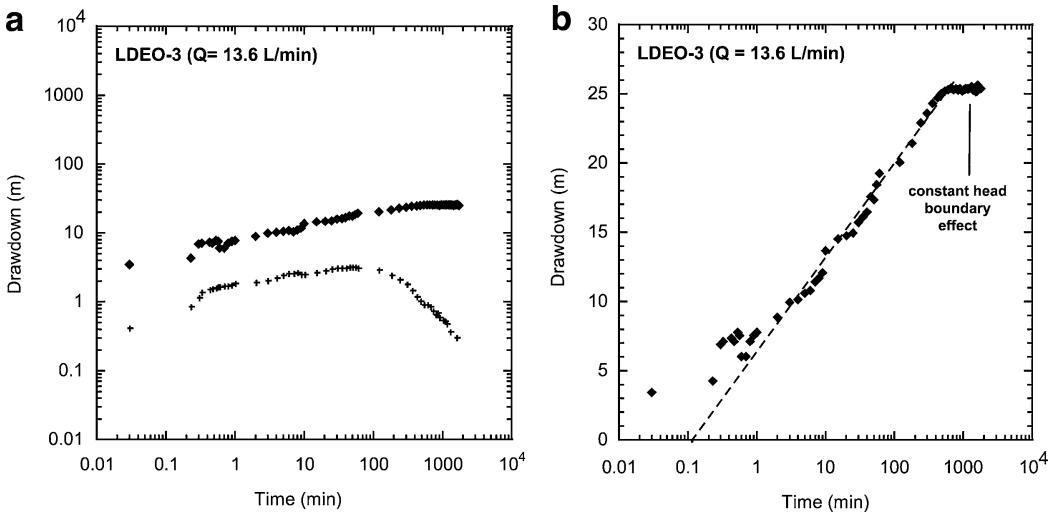

the well was assumed to be in static equilibrium. Water was injected at a constant rate of $13 \mathrm{l} / \mathrm{min}$ in LDEO-2 and of $6.6 \mathrm{l} / \mathrm{min}$ in LDEO-3. Head buildup during injection was measured with a high-resolution pressure transducer. Transmissivities were computed using the relation for flow into or out of a borehole developed by Cooper and Jacob (1946), which is valid for small borehole radii and sufficiently large injection times. Morin et al. (1988) describe in detail the method of calculating transmissivity values across layers bounded by the depths of the flowmeter measurements. In this study, a constant value of the storage coefficient $S=5.5 E-05$ is assumed based on typical ob-

Table 1 Calculated transmissivity values for LDEO-3 based on flowmeter logs, straddle-packer injection, and aquifer tests

\begin{tabular}{|c|c|c|}
\hline & Depth interval (m) & Transmissivity $\left(\mathrm{m}^{2} / \mathrm{s}\right)$ \\
\hline \multirow[t]{17}{*}{ Fluid injection } & $121-124$ & $\mathrm{a}$ \\
\hline & $132.5-135.5$ & $3.04 \mathrm{E}-07$ \\
\hline & $146-149$ & a \\
\hline & $161.5-164.5$ & a \\
\hline & $170.5-173.5$ & a \\
\hline & $180-183$ & a \\
\hline & $190.5-193.5$ & a \\
\hline & $209.5-212.5$ & a \\
\hline & $214.5-215.5$ & a \\
\hline & $218.5-221.5$ & a \\
\hline & $224.5-234.5$ & a \\
\hline & $227-230$ & $8.10 \mathrm{E}-08$ \\
\hline & $231.5-234.5$ & $1.62 \mathrm{E}-07$ \\
\hline & $260.5-263.5$ & a \\
\hline & $264-274$ & $2.17 \mathrm{E}-07$ \\
\hline & $271-274$ & a \\
\hline & $228-300$ & $9.95 \mathrm{E}-06$ \\
\hline \multirow[t]{7}{*}{ Flowmeter } & $115-230$ & a \\
\hline & $231-234$ & $1.39 \mathrm{E}-07$ \\
\hline & $235-241$ & $1.27 \mathrm{E}-07$ \\
\hline & $242-260$ & a \\
\hline & $261-266$ & $1.27 \mathrm{E}-07$ \\
\hline & $265-269$ & $1.62 \mathrm{E}-07$ \\
\hline & $269-275$ & $5.67 \mathrm{E}-07$ \\
\hline \multirow[t]{2}{*}{ Discharge test } & $110-227$ & a \\
\hline & $228-300$ & $6.28 \mathrm{E}-06$ \\
\hline
\end{tabular}

${ }^{\mathrm{a}}$ Data below detection limit of applied methods
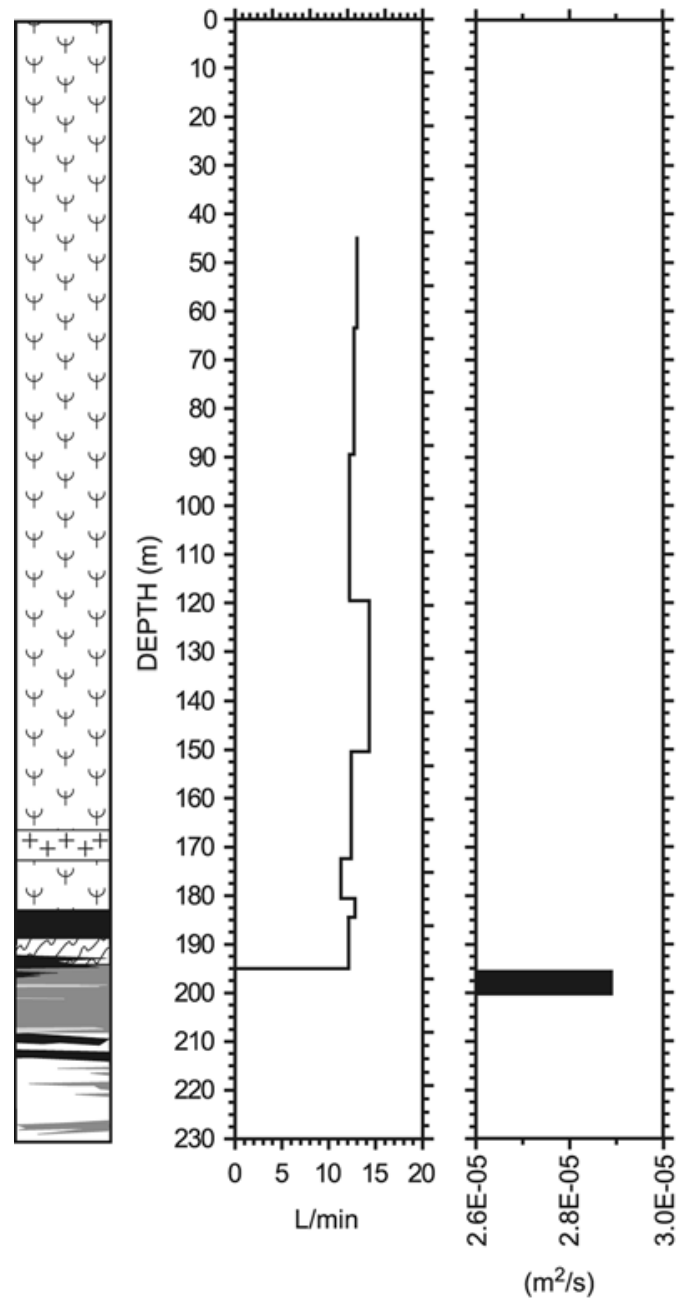

Fig. 7 Borehole flow profile and schematic litholog in LDEO-2 with an electromagnetic flowmeter concurrently with injection, after hydraulic head has approached a constant value. Transmissivity was calculated using the method of Cooper and Jacob (1946)

served values in fractured igneous rock (de Marsily 1981). Results of the flowmeter analysis are shown in Table 1.

Figures 7 and 8, respectively, illustrate the flowmeter logs in LDEO-2 and LDEO-3. A sharp reduction in flow between 196 and $200 \mathrm{~m}$ in LDEO-2 indicates fluid exchange between the borehole and the surrounding formation below this interval. Small variations above this depth 
Fig. 8 Borehole flow profile and schematic litholog in LDEO-3 with an electromagnetic flowmeter concurrently with injection, after the hydraulic head has approached a constant value. The vertical transmissivity profile is based on the flowmeter $\log$, as well as on fluid injection tests using a double-packer system
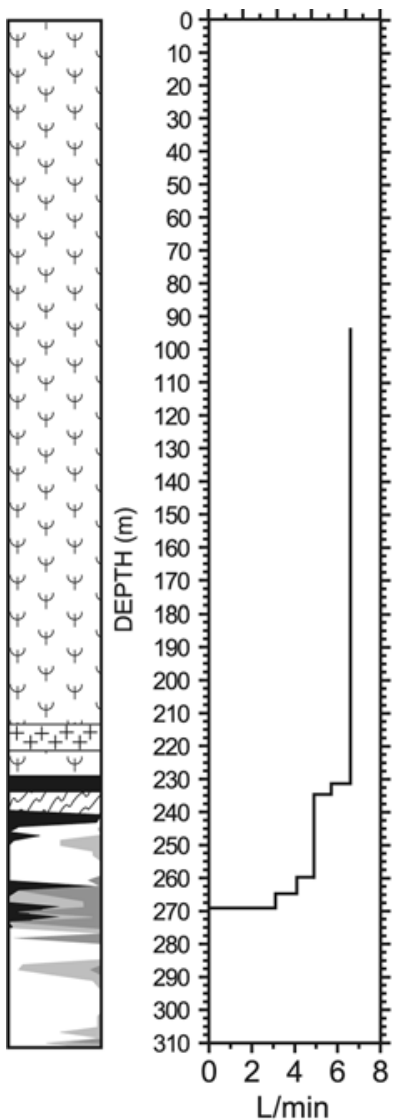

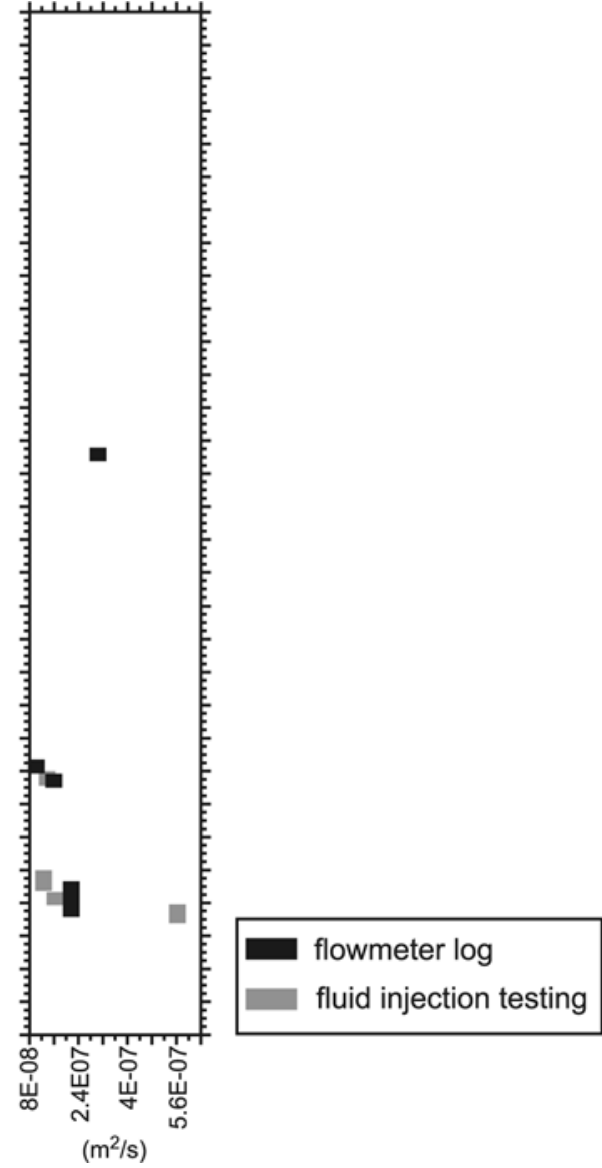

are due to measurement errors, caused by a poor seal at the flowmeter diverter. Leakage past the flowmeter's sensor is confirmed by the fact that the measured flow rate at $196 \mathrm{~m}$ is the same as the injection rate from the surface. The computed transmissivity in LDEO-2 below $196 \mathrm{~m}$ is $2.8 \mathrm{E}-05 \mathrm{~m}^{2} / \mathrm{s}$. In LDEO-3, five different zones of fluid flow are observed, ranging from 0.8 to $3.1 \mathrm{l} / \mathrm{min}$. The computed transmissivities vary between $1.27 \mathrm{E}-07$ and $5.67 \mathrm{E}-07 \mathrm{~m}^{2} / \mathrm{s}$ for these individual zones.

\section{Fluid-column logs}

Figure 2 shows that fluid resistivity in LDEO-2 varies between 87 and 93 ohm-m, corresponding to a specific conductivity between 107 and $114 \mu \mathrm{S} / \mathrm{cm}$ (fresh water), and increasing steadily to $170 \mathrm{~m}$ depth, where the values decrease sharply. This drop coincides with an increase in the temperature and indicates the presence of more conductive, warm water entering the borehole below this depth. The fluid resistivity and temperature logs throughout LDEO-3 are relatively constant, however with an average value of $31 \mathrm{ohm}-\mathrm{m}$ and a constant temperature gradient of $1^{\circ} \mathrm{C} / 100 \mathrm{~m}$, respectively (Fig. 3). The average vertical temperature gradient above $200 \mathrm{~m}$ in LDEO- 2 is $1.3^{\circ} \mathrm{C} / 100 \mathrm{~m}$. LDEO-3 temperatures may be mixed and cooled by surface water entering through open fractures above the ambient water level.

\section{Fracture distribution and orientation}

Acoustic and optical televiewer logs were used to study the orientation and the vertical distribution of fractures in the two boreholes. A total of 454 features were identified in LDEO-2 and 498 in LDEO-3. Figure 9 illustrates a compilation of all fractures with respect to depth for both boreholes, represented in fracture-density plots. An increase in the number of fractures approaching the sill-sediment contact zone is clearly observed in LDEO-3, and to a lesser extent in LDEO-2. Subhorizontal fractures are more abundant near the contact zone and the underlying sediments in both holes. The secondary peak in both the subvertical and subhorizontal fracture density in the upper part of LDEO-2 may be due to overburden release in these topographically exhumed rocks as well as greater resolution of the image $\log$ in LDEO-2, indicating thinner fractures.

\section{Discussion}

\section{Fracture transmissivity}

From these observations, the conductive fractures in LDEO-2 and LDEO-3 appear to occur in only four or five intervals near the sill-sediment contact zone and thin chilled dolerite layers below. These observations suggest that most of the fluid flow is concentrated within these relatively narrow intervals. They correlate well with the intrusive 
Fig. 9 Histograms of fracture counts over 5-m intervals in LDEO-2 and LDEO-3. The number of fractures generally increases towards the contact fracture density is high in the upper dolerite and near the contact zone in LDEO-2 zone in LDEO-3, whereas

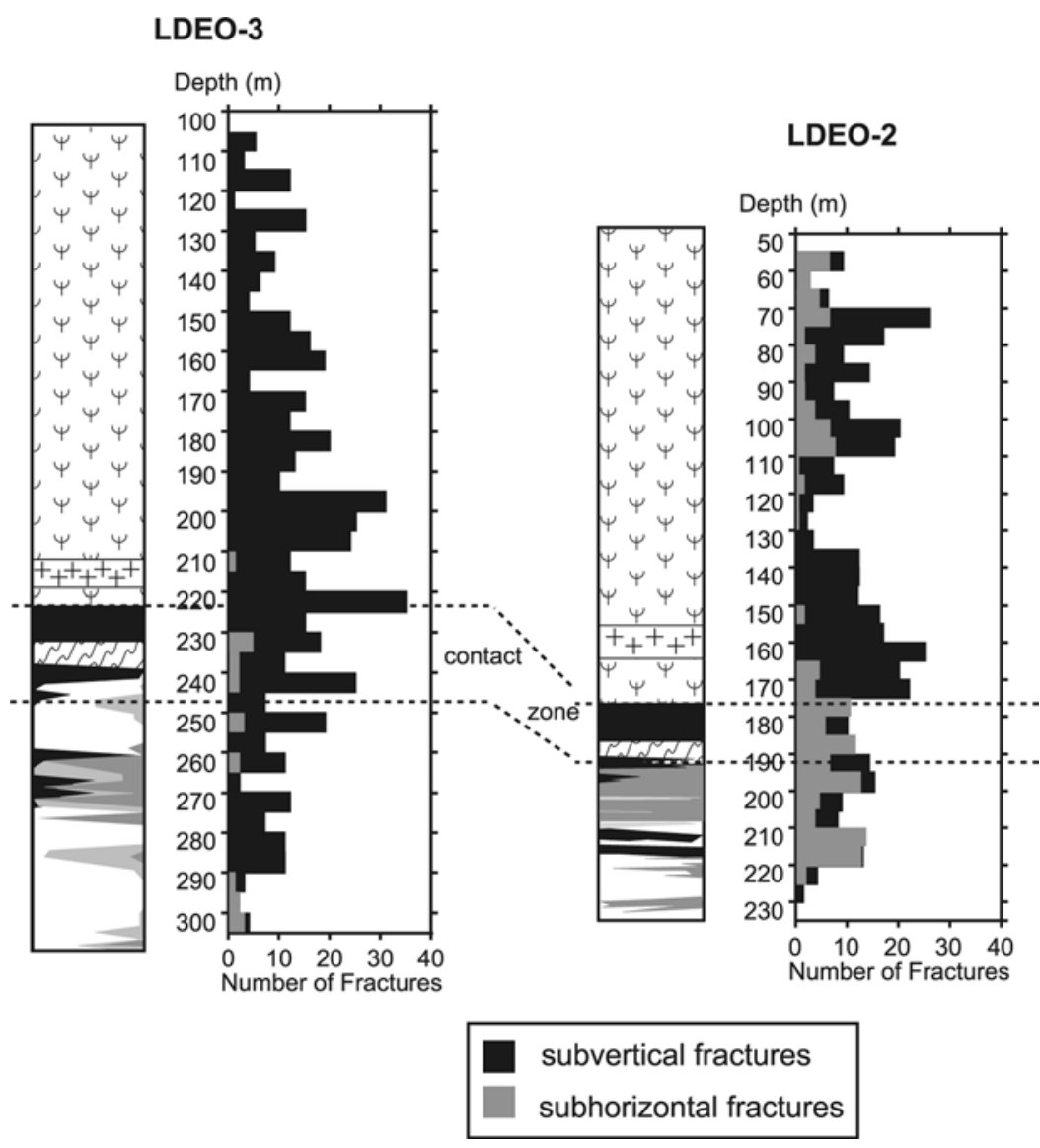

contact of the Palisades sill with the underlying sedimentary rocks, and are characterized by a complex geometry of disrupted depositional layering, chilled dolerite, contact metamorphosed sediments and altered breccias. Thermal cracking during the intrusion and subsequent metamorphism thus may have induced significant hydraulic conductivity, resulting in relatively thin and permeable layers. This result is consistent with the expected hydrodynamics of contact metamorphism. Hanson (1995) describes a comprehensive model for the development of permeability at intrusive contact zones. Following intrusion, fluid is produced from magma and the surrounding rocks, resulting in elevated fluid pressures and the formation of microcracks (hydrofracturing). As soon as cooling takes place, thermal contraction and fracturing occurs, and permeability significantly increases. The effect of thermal fracturing and its implications for the hydraulic conductivity distribution in field settings has been described by Kuntz et al. (2002) and Welhan et al. (2002) for flood basalts in the eastern Snake River plain, northwestern USA.

The flowmeter and the fluid injection tests demonstrate that the distribution of transmissivity in the two LDEO holes is not primarily a function of the fracture density or orientation. Despite being highly fractured, low transmissivity (below the detection limit of the methods) is observed in the sill above the contact zone. BHTV image analysis indicates two distinct fracture populations in the dolerite sill and underlying sedimentary rocks. Steeply dipping frac- tures striking E-W and NE-SW occur throughout the holes (Fig. 10). Subhorizontal fractures are concentrated near the contact zone and below in the sedimentary rocks. The calculated transmissivity in the contact and below is also 2 orders of magnitude greater in LDEO-2 than in LDEO-3. Some degree of lateral continuity between the fracture populations is possible, however the likelihood of this cannot be confirmed by single-hole packer and image data alone. A pressure sensor, installed in LDEO-2 was not responsive to hydraulic head changes during the $30-\mathrm{h}$ constant discharge test in LDEO-3. Any potential hydraulic communication over the 450-m lateral distance between the two holes may be cut off by an offset in the stratigraphic position of conductive intervals in the two holes. Vertical hydraulic connections between different stratigraphic layers near the contact zone was also not observed, indicating the importance of the subtle differences in lithology at the two nearby locations.

The subvertical fracture system does not contribute substantially to the overall transmissivity of the dolerite sill or the underlying sedimentary rocks in this area. Schlische (1992) and Goldberg et al. (2003) discuss the steeply dipping, NE-SW striking fractures set within the Newark basin rocks that were formed during the Late Triassic extension and subsidence of the rift basin. They also suggest compression and exhumation in the Early Jurassic that caused the formation of the subhorizontal fracture population and cracks. Many of these subvertical and subhorizontal frac- 
Fig. 10 Histograms of fracture fractures identified in LDEO-2 and LDEO-3 using acoustic BHTV logs. Rosette diagrams of the strike of fractures and Kamb contour stereograms of poles to the fracture planes are shown dip vs. frequency for all
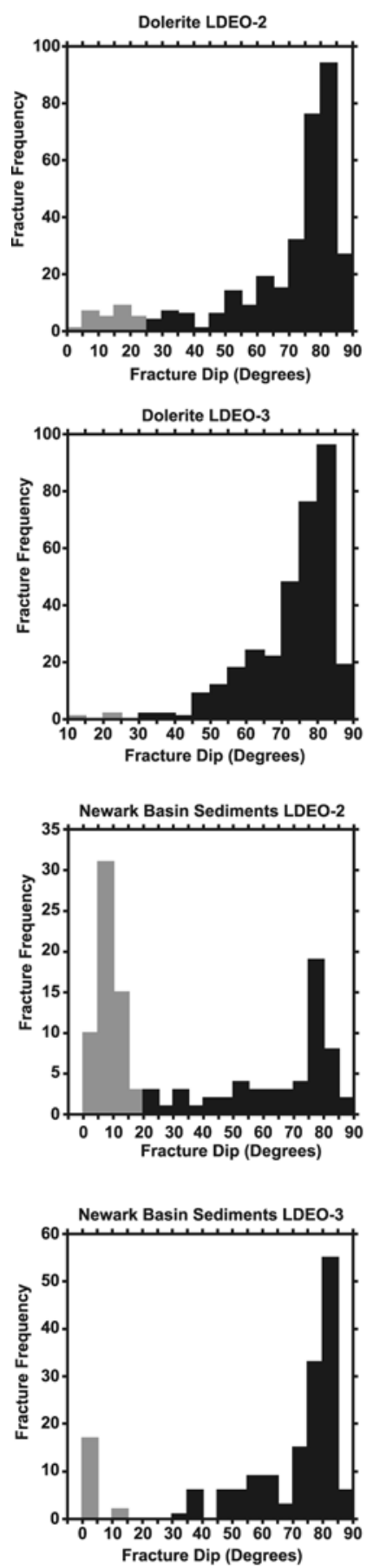

tures are also filled (Goldberg et al. 2003). If compression of the basin during the Early Jurassic caused the closure of the pre-existing subvertical fractures, and subsequent uplift and exhumation caused horizontal fracturing in the sediments, the latter set would presumably remain open during intrusion of the Palisades sill. Outcrops of the sill confirm that subvertical fractures are generally closed joints that do not interconnect (e.g. Merguerian and Sanders 1995; Naslund 1998). Although some subvertical fractures may not be intersected by vertical drill holes, flow measure-
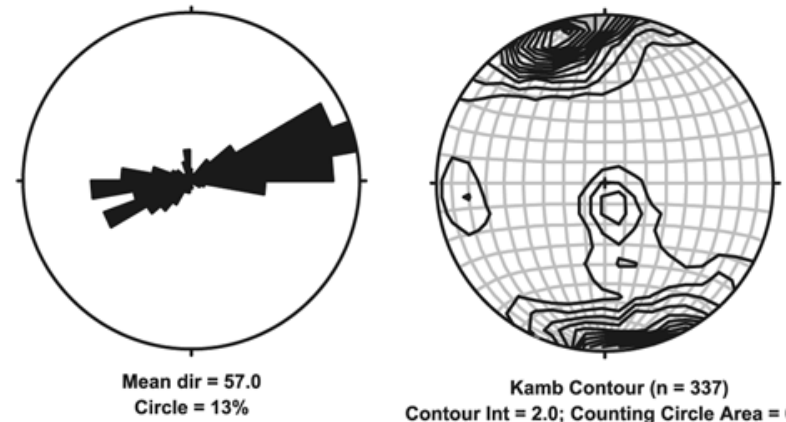

Kamb Contour $(n=337)$ Contour Int $=2.0$; Counting Circle Area $=0.026$ Significance Level $=\mathbf{3 . 0}$ sigma
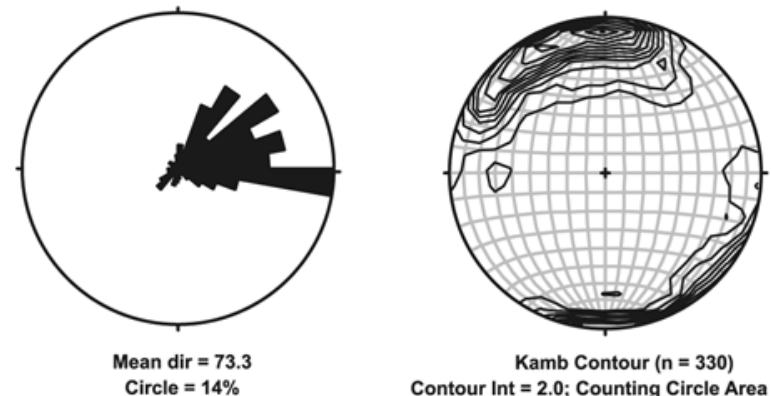

Kamb Contour $(n=330)$ Contour Int = 2.0; Counting Circle Area $=0.027$ Significance Level $=\mathbf{3} .0$ sigma
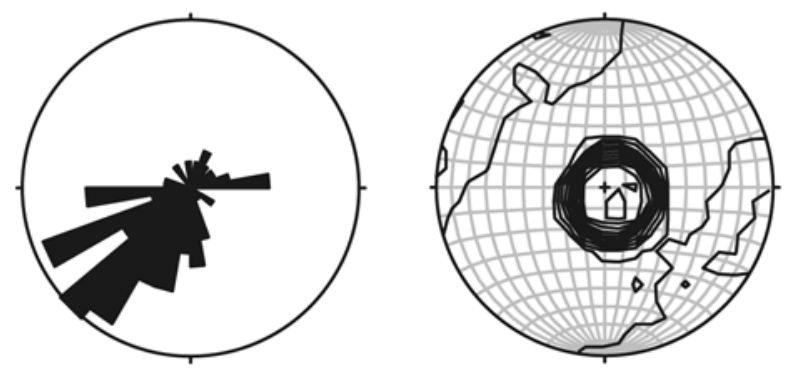

Mean $\mathrm{dir}=\mathbf{2 1 7 . 0}$ Circle $=11 \%$

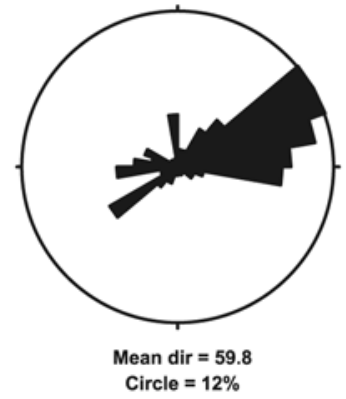

Kamb Contour $(n=117)$ Contour Int $=2.0$; Counting Circle Area $=0.071$ Significance Level $=3.0$ sigma

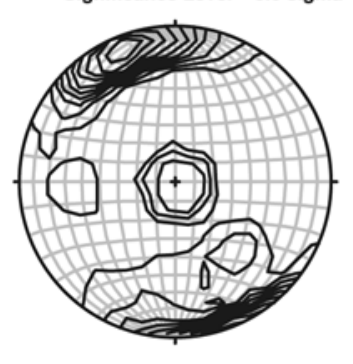

Kamb Contour ( $n=168$ ) Contour Int $=2.0$; Counting Circle Area $=0.051$ Significance Level $=3.0$ sigma

ments in LDEO-2 and LDEO-3 confirm that these fracture sets do not contribute significantly to the bulk transmissivity of the formations. Inclined drill holes would increase the probability of intersecting vertical fractures, which could increase the measured transmissivity (e.g. Nativ et al. 2003). 


\section{Flow regime}

In this study, the short-duration fluid injection tests allow estimates of formation transmissivity over narrow depth intervals. The longer-duration constant discharge test yields information about the hydraulic response over a large interval in LDEO-3. These data reveal that radial flow conditions are established after $\sim 1$ min pumping time (Fig. $6 a$ and $b$ ). The later response (>200 min) indicates a decline in the drawdown, likely a boundary-dominated response, which is most clearly illustrated by its derivative. The derivative curve indicates a constant head boundary by the monotonically declining curve on the log-log plot and by a flat line on the semi-logarithmic plot (Horne 1995). An obvious constant head boundary near this location is the Hudson River, located only 900 m east of LDEO-3.

Transmissivity values computed from three different hydrologic tests (flowmeter, fluid injection and constant discharge tests) all reveal similar values over the contact interval. Transmissivity computed from flowmeter and fluid injection in LDEO-3 is quite similar and approaches at depths below the main dolerite the high end-member estimate computed from constant discharge tests between 228 and $300 \mathrm{~m}$. Although the single-well drawdown test may underestimate the transmissivity, a comparison of this result with the sum of the values estimated from flowmeter measurements spanning the 228-300 m interval are of the same order of magnitude and within the intrinsic error of the measurements. Paillet (1998) demonstrated that flowmeter measurements delineate only the largest transmissivities in a borehole over a range of about two orders of magnitude. It can be concluded that transmissive zones undetected by the flowmeter therefore do not significantly contribute to the bulk transmissivity.

The electrical logs recorded in LDEO-2 and LDEO-3 indicate that the dolerite is highly resistive compared to the contact zone and the underlying sedimentary rocks. Burgdorff and Goldberg (2001) calculated porosity values from resistivity logs, which ranged from $3 \%$ in the fresh dolerite to maximum values of $30 \%$ in the contact zone and the underlying sediments. In addition, the shallow and deep resistivity logs in LDEO-2 diverge in the dolerite and converge towards the contact zone and in the sedimentary rocks. The separation between the shallow and deep resistivity, and shallow resistivity values greater than the deep ones suggests dominant vertical fracturing in the dolerite, whereas the convergence of the shallow and deep resistivity logs indicate greater horizontal fracturing near the contact zone and the underlying sedimentary rocks (e.g. Pezard 1990). This supports the evidence about the two fracture populations provided by direct acoustical and optical image logs.

Hydraulic testing and geophysical logging in two boreholes indicate that the contact zone between the Palisades sill and the underlying Newark rift basin sedimentary rocks is the predominant transmissive unit that controls fluid flow at this location. The implication of this study is that intrusions may behave in a similar manner, with focused fracture transmissivity at contact boundaries with the country rock, and possibly between different flow units. Further experiments with multiple holes distributed across intrusive contacts would support the application of this work more broadly in other geological settings. On a more local scale, this hydrogeological framework provides constraints for an ongoing carbon dioxide injection experiment from which a quantitative evaluation of the potential of long-term $\mathrm{CO}_{2}$ sequestration in igneous rocks is developed (Matter et al. 2002).

\section{Conclusions}

1. Highest transmissivity values, determined from flowmeter measurements and fluid injection test cluster within the main contact zone and within the interval that is characterized by the occurrence of small layers of chilled dolerite below the main contact zone. The distribution of the conductive intervals in the two boreholes is not primarily a function of the two main fracture populations and their density. Despite being highly fractured the dolerite above and the sedimentary rocks below the contact zones appears to be significantly less conductive.

2. The correlation between the intervals with the highest transmissivity and the intrusion path of the Palisades sill implies that permeability was induced by the intrusion of the sill and subsequent thermal fracturing (contact metamorphism) and cracking of the surrounding rocks.

3. Lateral and vertical hydraulic communication over the 450-m lateral distance between LDEO-2 and LDEO-3, as well as between the dolerite sill and the underlying sedimentary rocks, are restricted, demonstrating that the transmissivity within the vertical or subvertical fracture system is insignificant and that fluid flow between different stratigraphic levels is not occurring.

4. Geophysical logs, such as the electrical resistivity display less resistive rock within the contact zone and the underlying sedimentary rocks, and calculated fracture porosities based on these logs are up to $30 \%$ in the contact zone and the sediments. Fluid column logs do not necessarily indicate zones of active fluid exchange between the boreholes and the surrounding rocks.

Acknowledgements This study was funded by the Lamont-Doherty Earth Observatory and the Earth Institute of Columbia University. Field work and data acquisition was substantially supported by W. Masterson, G. Myers (LDEO), and B. Corland (U.S. Geological Survey). Lamont-Doherty Earth Observatory contribution number 6725.

\section{References}

Bear J (1979) Hydraulics of groundwater. McGraw-Hill, New York Bourdet D, Ayoub JA, Pirard YM (1989) Use of pressure derivative in well-test interpretation. SPE Formation Evaluation, pp 293-302

Burgdorff K, Goldberg D (2001) Petrophysical characterization and natural fracturing in an olivine-dolerite aquifer. Electr Geosci $6: 3$

Chen RH, Lee CW, Chen CS (2001) Evaluation of transport of radioactive contaminant in fractured rock. Environ Geol 41:440-450 
Cooper HH, Jacob CE (1946) A generalized graphical method for evaluating formation constants and summarizing well-field history. EOS Trans AGU 27:526-534

de Marsily G (1981) Quantitative hydrogeology: hydrogeology for engineers. Academic Press, London

Ericsson LO, Almen KE (1992) The Aspo Hard Rock Laboratory; overview of pre-investigations and monitoring. In: Tillerson JR, Wawersik WR (eds) Symposium on rock mechanics. AA Balkema, pp 171-180

Faybishenko B, Witherspoon PA, Benson SM (2000) Dynamics of fluids in fractured rock. Am Geophys Union Geophy Monogr 122

Finsterle S, Fabryka-Martin JT, Wang JSY (2002) Migration of a water pulse through fractured porous media. J Contam Hydrol 54:37-57

Goldberg D, Burgdorff K (2005) Natural fracturing and petrophysical properties of the Palisades dolerite sill. In: Harvey PK, Brewer TS, Pezard PA, Petrov VA (eds) Petrophysical properties of crystalline rocks. Geol Soc Lond Spec Publ

Goldberg D, Lupo T, Caputi M, Barton C, Seeber L (2003) Stress regimes in the Newark Basin Rift: evidence from core and downhole data. In: Le Tourneau P, Olsen P (eds) The great rift valleys of Pangea in eastern North America. Columbia Press, New York, pp 87-99

Goldberg DS, Reynolds DJ, Williams CF, Witte WK, Olsen P, Kent DV (1994) Well logging results from the Newark Rift Basin Coring Project. Scient Drill 4:267-279

Guimerà J, Carrera J (2000) A comparison of hydraulic and transport parameters measured in low-permeability fractured media. J Contam Hydrol 41:261-281

Hanson RB (1995) The hydrodynamics of contact metamorphism. GSA Bull 107:595-611

Horne RN (1995) Modern test well analysis: a computer-aided approach, 2nd edn. Petroway Inc., Palo Alto

Houghton HF (1990) Hydrogeology of the Early Mesozoic rocks of the Newark Basin, New Jersey. In: Aspects of groundwater in New Jersey, 7th annual meeting of the Geol Assoc of New Jersey, Geol Assoc of New Jersey, Union, New Jersey

Kuntz MA, Anderson SR, Champion DE, Lanphere MA, Grunwald DJ (2002) Tension cracks, eruptive fissures, dikes, and faults related to late Pleistocene-Holocene basaltic volcanism and implications for the distribution of hydraulic conductivity in the eastern Snake River plain, Idaho. Spec Pap Geol Soc Am 353:111-133

Long JCS, Aydin A, Brown SR, Einstein HH, Hestir K, Hsieh PA, Myer LR, Nolte KG, Norton DL, Olsson OL, Paillet FL, Smith JL, Thomsen L (1996) Rock fractures and fluid flow: contemporary understanding and applications. National Academy Press, Washington, DC

Matter JM, Takahashi T, Goldberg D, Morin RH, Stute M (2002) Secure, long-term geological carbon sequestration in mafic igneous rocks: results from field and laboratory experiments. In: Proc GSA Ann Meet, Denver, CO, Abstract with Program vol. 34(6):305

Mazurek M (2000) Geological and hydraulic properties of waterconducting features in crystalline rocks. In: Stober I, Bucher K (eds) Hydrogeology of crystalline rocks. Kluwer, Dordrecht, pp 3-26

Merguerian C, Sanders JE (1995) Late syn-intrusive clastic dikes at the base of the Palisades intrusive sheet, Fort Lee, NJ, imply a shallow ( 23 to $4 \mathrm{~km})$ depth intrusion. In: Hanson GN (ed) Geology of Long Island and metropolitan New York. State University of New York, Stony Brook, NY, pp 54-63

Michalski A (1990) Hydrogeology of the Brunswick (Passaic) Formation and implications for ground water monitoring practices. Ground Water Monit Rev 10:134-143

Michalski A, Britton R (1997) The role of bedding fractures in hydrogeology of sedimentary bedrock - evidence from the Newark Basin, New Jersey. Ground Water 35:318-327
Molz FJ, Bowman GK, Young SC, Waldrop WR (1994) Borehole flowmeters - field application and data analysis. J Hydrol 163:347-371

Molz FJ, Morin RH, Hess AE, Melville JG, Güven O (1989) The impeller meter for measuring aquifer permeability variations: evaluation and comparison with other tests. Water Resour Res 25:1677-1683

Morin RH, Senior LA, Decker ER (2000) Fractured-aquifer hydrogeology from geophysical logs: Brunswick Group and Lockatong Formation, Pennsylvania. Ground Water 38:182-192

Morin RH, Carleton GB, Poirier S (1997) Fractured-aquifer hydrogeology from geophysical logs: The Passaic Formation, New Jersey. Ground Water 35:328-338

Morin RH, Hess AE, Paillet FL (1988) Determining the distribution of hydraulic conductivity in a fractured limestone aquifer by simultaneous injection and geophysical logging. Ground Water 26:587-595

Naslund HR (1998) The Palisades sill, New York and New Jersey. In: Naslund HR (ed) Field trip guide for the 70th annual meeting of the New York State Geological Association

Nativ R, Adar E, Assaf L, Nygaard E (2003) Characterization of the hydraulic properties of fractures in chalk. Ground Water 41:532-543

Olsen P (1980) The latest Triassic and Early Jurassic formations of the Newark Basin (eastern North America, Newark Supergroup): stratigraphy, structure, and correlation. New Jersey Acad Sci Bull 25:25-51

Olsen P, Kent DV (1996) Milankovitch climate forcing in the tropics of Pangaea during the Late Triassic. Palaeogeogr Palaeoclimatol Palaeoecol 122:1-26

Paillet FL (1998) Flow modeling and permeability estimation using borehole flow $\operatorname{logs}$ in heterogeneous fractured formations. Water Resour Res 34:997-1010

Paillet FL, Reese RS (2000) Integrating borehole logs and aquifer tests in aquifer characterization. Ground Water 38:713-725

Pezard PA (1990) Electrical properties of mid-ocean ridge basalt and implications for the structure of the upper oceanic crust in hole 504B. J Geophys Res 95:9237-9264

Schlische RW (1992) Structural and stratigraphic development of the Newark extensional basin, eastern North America: evidence for the growth of the basin and its bounding structures. Geol Soc Am Bull 104:1246-1263

Schlische RW, Olsen P (1990) Quantitative filling model for continental extensional basins with applications to Early Mesozoic rifts of eastern North America. J Geol 98:135-155

Shapiro AM, Hsieh PA (1998) How good are estimates of transmissivity from slug tests in fractured rock? Ground Water 36:37-48

Singhal BBS, Gupta RP (1999) Applied hydrogeology of fractured rocks. Kluwer, Dordrecht

Van Houten FB (1969) Late Triassic Newark Group, north-central New Jersey and adjacent Pennsylvania and New York. In: Subitzky S (ed) Geology of selected areas in New Jersey and eastern Pennsylvania and guidebook of excursions. Geol Soc Am Ann Meet, Atlantic City, 1969, Rutgers University Press, pp 314-347

Walker KR (1969) A mineralogical, petrological, and geochemical investigation of the Palisades sill, New Jersey. Mem Geolog Soc Am 115:175-187

Welhan JA, Johannesen CM, Reeves KS, Clemo TM, Glover JA, Bosworth KW (2002) Morphology of inflated pahoehoe lavas and spatial architecture of their porous and permeable zones, eastern Snake River Plain, Idaho. Geol Soc Am Spec Pap 353:135-150

Witherspoon PA, Cook NGW, Gale JE (1980) Geologic storage of radioactive waste; results from field investigations at Stripa, Sweden. In: Post RG (ed) Waste management, part 2. Arizona Board of Regents, Tucson

Young SC, Pearson HS (1995) The electromagnetic borehole flowmeter: description and application. Ground Water Monit Remed 15:138-147 